\title{
Effect of long-term cimetidine on gastric acid secretion, serum gastrin, and gastric emptying
}

\author{
J. A. H. FORREST, M. R. FETTES, G. P. McLOUGHLin, AND R. C. HEADiNG \\ From the University Department of Therapeutics and Clinical Pharmacology and Department of Medical \\ Physics, Royal Infirmary, Edinburgh
}

SUMMARY Gastric acid secretion, gastric emptying, fasting serum gastrin and the serum gastrin response to a meal were measured in duodenal ulcer patients before, and at least five days after completing prolonged treatment with cimetidine ( 1 or $2 \mathrm{~g}$ /day for four or eight weeks followed by $600 \mathrm{mg}$ twice daily for six months). Fasting serum gastrin and the gastrin response were also measured during treatment. Compared with pretreatment values, fasting serum gastrin concentrations were raised both during and five to 31 days after stopping treatment $(P \leqslant 0.02)$. The integrated gastrin response and the rate of gastric emptying of the solid component of the meal were increased during treatment $(\mathrm{P}<0.001$ and $\mathrm{P}<0.02$ respectively) but returned to pretreatment levels after stopping therapy. No significant changes were observed in the basal or maximal acid outputs or the rate of emptying of the liquid component of the meal. The results imply that the hypergastrinaemia associated with long-term cimetidine therapy does not result in increased gastric acid secretion.

The effects of a single dose of the histamine $\mathrm{H}_{2}$ receptor antagonist cimetidine on gastric secretion, fasting gastrin concentrations, the serum gastrin response to a meal, and gastric emptying are well established (Heading et al., 1977; Richardson, 1978). The effects of short courses of treatment on gastric secretion and basal gastrin concentrations have also been described (Bank et al., 1977; Holden et al., 1977; Sewing et al., 1978; Winship, 1978), but information on the effects of long-term therapy is limited (Spence et al., 1977; Bodemar and Walan, 1978). We have therefore examined the effect of long-term cimetidine therapy ( 1 or $2 \mathrm{~g} /$ day for fuur or eight weeks followed by $600 \mathrm{mg}$ twice daily for six months) on gastric acid secretion, fasting gastrin concentrations, the serum gastrin response to a meal, and gastric emptying rates.

\section{Methods}

After endoscopic confirmation of an active duodenal ulcer, patients were entered into the study provided that they had not previously been treated with cimetidine. Gastric acid secretion, fasting serum gastrin concentration, the serum gastrin response to a standard meal, and gastric emptying rates of both liquid and solid components of the meal were

Received for publication 20 November 1978 assessed, all drugs being stopped a minimum of 48 hours beforehand. Patients were then treated with cimetidine ( 1 or $2 \mathrm{~g}$ daily in divided doses) for four or eight weeks until there was endoscopic evidence that the ulcer had healed. They then received $600 \mathrm{mg}$ of cimetidine twice daily for six months. The fasting gastrin, the gastrin response to the meal, and gastric emptying studies were repeated after three months' treatment with $600 \mathrm{mg}$ twice daily, while the patients were still taking the drug. These began one to two hours after the patient had taken the $600 \mathrm{mg}$ morning dose of cimetidine. All studies were repeated at least five days after completion of therapy with $600 \mathrm{mg}$ twice daily.

\section{GASTRIC ACID SECRETION}

After an overnight fast, a size 14 Ryle's tube was passed and its position in the stomach checked by means of a water recovery test. Basal acid output (BAO) was measured over one hour and after the subcutaneous injection of pentagastrin $(6 \mu \mathrm{g} / \mathrm{kg}$ bodyweight), the maximal acid output (MAO) was determined over the subsequent hour.

\section{SERUM GASTRIN AND GASTRIC EMPTYING} STUDIES

These were carried out simultaneously. After an overnight fast, two blood samples were taken 15 minutes apart for measurement of fasting serum 
gastrin concentrations. The patient then ate a meal consisting of Carnation breakfast food, milk, biscuits, and cheese $(50 \mathrm{~g}$ protein, $55 \mathrm{~g}$ carbohydrate, and $40 \mathrm{~g}$ fat) containing indium-113m diethylenetriaminepenta-acetic acid as a radioactive marker of the liquid component and approximately 30 small paper particles labelled with $99 \mathrm{~m}$-technetium sulphur colloid as a marker of the solid component of the meal. Gastric emptying rates of the two markers were then determined by a scintigraphic method (Heading et al., 1976). The emptying rate of the liquid marker was expressed as an emptying halftime $\left(\mathrm{T}_{2} \frac{1}{2}\right)$; solid marker emptying being expressed as a zero order rate constant ( $\%$ technetium emptied per minute) as it approximates more closely to a linear function with time than to an exponential (Heading et al., 1976).

Blood samples for serum gastrin measurements were taken at intervals for three hours after meal ingestion and stored at $-40^{\circ} \mathrm{C}$ until assayed in duplicate by radioimmunoassay. All the samples obtained from each patient's three studies were measured in the same batch. The specificity and accuracy of the assay were as previously described (Heading et al., 1977).

Statistical analyses were performed using Wilcoxon's paired signed rank tests.

\section{Results}

\section{GASTRIC ACID SECRETION}

The BAO and MAO before starting treatment and a mean of $11 \cdot 4$ days (range: 6-28 days) after completing treatment are shown in Table 1. Although the median BAO and MAO were increased by $28 \%$ and $8 \%$ respectively after completing treatment, the changes were not statistically significant. There was no correlation between individual changes in BAO and MAO and the number of days after stopping the drug on which the second test was performed.

Table 1 Gastric acid secretion in 22 duodenal ulcer patients before and after cimetidine therapy

\begin{tabular}{lll}
\hline & \multicolumn{2}{l}{ Acid output $\left(\mathrm{mmol} \boldsymbol{h}^{-1}\right)$} \\
\cline { 2 - 3 } & Basal & Maximal \\
\hline Before treatment & 2.72 & 30.4 \\
After treatment & 3.49 & 32.7 \\
\hline
\end{tabular}

Results are medians.

\section{SERUM GASTRIN STUDIES}

In comparison with pretreatment values, fasting gastrin concentrations were increased by $26 \%$ while patients were on treatment $(P<0.01)$ and by $21 \%$ a mean of 13.8 days (range: 5-31 days) after stopping
Table 2 Effects of cimetidine on basal serum gastrin concentrations and on the 150-minute integrated gastrin response (IGR) to a meal in 17 duodenal ulcer patients

\begin{tabular}{lll}
\hline & $\begin{array}{l}\text { Basal serum gastrin } \\
\text { conc. }\left(p g-h \mathrm{ml}^{-1}\right)\end{array}$ \\
\hline Before treatment & 53.5 & 228.6 \\
During treatment & 67.5 & 580.8 \\
After treatment & 65.0 & 291.6 \\
\hline
\end{tabular}

Results are medians.

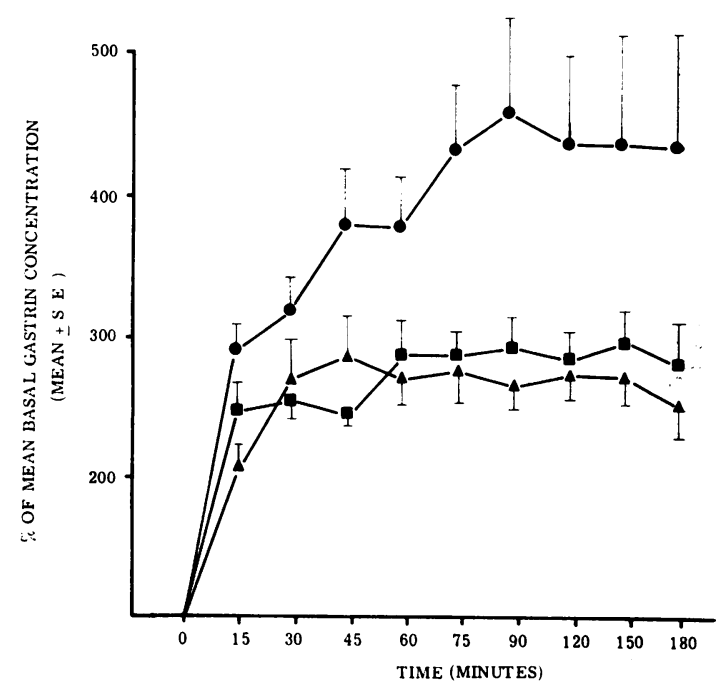

Figure Serum gastrin concentrations expressed as $\%$ of mean basal concentrations in 17 duodenal ulcer patients given the standard meal. Bars are $\pm 1 S E$. Before cimetidine. After three months of cimetidine. $\Delta-\Delta$ Five to 31 days after stopping cimetidine after six months' treatment.

therapy $(P=0.02)$ (Table 2). Higher concentrations were observed in 16 of the 17 patients during treatment and in 13 of the 17 patients after treatment. The serum gastrin response to the standard meal is shown in the Figure and the 150-minute integrated gastrin response (IGR) in Table 2. Compared with pretreatment values, the IGR was increased by $154 \%$ $(P<0.001)$ while on treatment with a return to pretreatment levels after completion of treatment. There were no correlations between the pretreatment BAO or MAO and the percentage rise in the IGR during therapy $(r=0.11$ and $0.02 ; P>0.1)$. There was no correlation between the individual changes in IGR before and after stopping treatment and the number of days after stopping the drug on which the test was performed.

GASTRIC EMPTYING

During treatment, there was a $77 \%$ increase in the 
rate of emptying of the solid marker in the meal $(P<0.02)$ (Table 3); this returning to pretreatment levels after completion of therapy. There was no significant change in the emptying of the liquid marker.

Table 3 Effects of cimetidine on gastric emptying rates of indium-113m (liquid marker) and $99 m$-technetium (solid marker) in 16 duodenal ulcer patients

\begin{tabular}{lll}
\hline & $\begin{array}{l}\text { Indium } T \frac{1}{2} \\
(\text { min })\end{array}$ & $\begin{array}{l}\% \text { Technetium } \\
\text { emptied } \\
\text { min }^{-1}\end{array}$ \\
\hline Before treatment & 57.9 & 0.13 \\
During treatment & 61.5 & 0.23 \\
After treatment & 51.4 & 0.19 \\
\hline
\end{tabular}

Results are medians.

\section{Discussion}

We have previously shown that a single dose of cimetidine given to normal subjects does not alter gastric emptying of either the liquid or solid components of a meal (Heading et al., 1977). Although the present results show increases in mean gastric emptying rates for both components of the meal during and after completion of cimetidine therapy, the only significant change was observed in the rate of emptying of the solid component during therapy. As acid is an inhibitor of gastric emptying (Hunt and Knox, 1972), its inhibition during cimetidine therapy may result in a differential effect on the rate of emptying of the two components of the meal.

It has previously been reported that fasting serum gastrin levels are unaffected by a single dose of cimetidine (Richardson, 1978). After a short course of the drug, one investigator has reported no change in fasting gastrin levels (Bank et al., 1977), and another an increase (Sewing et al., 1978). We have found a significant rise in fasting serum gastrin concentrations during treatment and also after completion of six months' treatment. However, the changes were small and seem unlikely to have clinical relevance.

The demonstrations that the integrated gastrin response to a meal is enhanced by single doses of cimetidine (Heading et al., 1977; Richardson, 1978) has led to concern that prolonged therapy might cause parietal cell hyperplasia and a rebound in gastric acid secretion above pretreatment levels when therapy is stopped. Our present results confirm that the IGR to food is enhanced while the drug is being given but indicate that the response returns quickly to normal when the drug is withdrawn. Basal and maximal acid secretion rates after treatment are, however, no different from values before treatment, indicating that the hypergastrinaemia has not resulted in an increase in the parietal cell mass.

Our results of acid secretion are in agreement with those of Bodemar and Walan (1978) who found that when cimetidine was stopped there was no increase in gastric acid output over pretreatment levels. Their estimations of acid output, however, were carried out only two days after stopping therapy. The interval between withdrawal of therapy and our measurements of acid secretion approximates much more closely to the reported interval between withdrawal of therapy and severe recurrent duodenal ulceration (Wallace et al., 1977). Thus, although treatment with cimetidine is associated with a hypergastrinaemia, there is no excessive rebound in acid secretion after withdrawal of the drug and recurrence of duodenal ulceration at this time cannot be due to this mechanism.

We thank Dr G. E. Lidgard, Regional Hormone Centre, Royal Infirmary, Edinburgh, and Mr F. C. Logue, Radioimmunoassay Unit, Royal Infirmary, Glasgow, for estimation of serum gastrin.

\section{References}

Bank, S., Barbezat, G. O., Vinik, A. I., and Helman, C. (1977). Serum gastrin levels before and after 6 weeks of cimetidine therapy in patients with duodenal ulcer. Digestion, 15 157-161.

Bodemar, G., and Walan, A. (1978). Maintenance treatment of recurrent peptic ulcer by cimetidine. Lancet, 1 , 403-407.

Heading, R. C., Logan, R. F. A., McLoughlin, G. P., Lidgard, G., and Forrest, J. A. H. (1977). Effect of cimetidine on gastric emptying. In Cimetidine. Edited by W. L. Burland and M. A. Simkins, pp. 145-162. Excerpta Medica: Amsterdam.

Heading, R. C., Tothill, P., McLoughlin, G. P., and Shearman, D. J. C. (1976). Gastric emptying rate measurement in man. A double isotope scanning technique for simultaneous study of liquid and solid components of a meal. Gastroenterology, 71, 45-50.

Holden, R. J., Hearns, J. B., McKibben, B., Buchanan, K. B., and Crean, G. P. (1977). Long-term effects of cimetidine on gastric secretion (Abstract). Gut, 18, A949.

Hunt, J. N., and Knox, M. T. (1972). The slowing of gastric emptying by four strong acids and three weak acids. Journal of Physiology, 222, 187-208.

Richardson, C. T. (1978). Effect of $\mathbf{H}_{2}$-receptor antagonists on gastric acid secretion and serum gastrin concentration. Gastroenterology, 74, 366-370.

Sewing, K. F., Hagie, L., Ippoliti, A. F., Isenberg, J. I., Samloff, I. M., and Sturdevant, R. A. L. (1978). Effect of one-month treatment with cimetidine on gastric secretion and serum gastrin and pepsinogen levels. Gastroenterology (suppl.), 74, 376-379.

Spence, R. W., Celestin, L. R., McCormick, D. A., and Owens, C. J. (1977). The effect of three months' treatment with cimetidine on basal and 'Oxo'-stimulated serum gastrin. In Cimetidine. Edited by W. L. Burland and M. A. 
Simkins, pp. 163-176. Excerpta Medica: Amsterdam.

Wallace, W. A., Orr, C. M. E., and Bearn, A. R. (1977).

Perforation of chronic peptic ulcers after cimetidine.
British Medical Journal, 2, 865-866.

Winship, D. H. (1978). Cimetidine in the treatment of duodenal ulcer. Gastroenterology, 74, 402-406.

\section{The April 1979 Issue}

\section{THE APRIL 1979 ISSUE CONTAINS THE FOLLOW PAPERS}

Immune status in Crohn's disease. 3. Peripheral blood B lymphocytes, enumerated by means of $F(a b)_{2}$-antibody fragments, Null and $T$ lymphocytes I. O. AUER, S. GÖTZ, E. ZIEMER, H. MALCHOW, AND H. EHMS

The granuloma in Crohn's disease T. J. CHAMBERS AND B. C. MORSON

Measuring intraepithelial lymphocytes, surface area, and volume of lamina propria in the jejunal mucosa of coeliac patients M. GUIX, J. M. SKINNER, AND R. WHITEHEAD

Endoscopic retrograde brush cytology in patients with primary and secondary malignancies of the pancreas M. OSNES, A. SERCK-HANSSEN, $O$. KRISTENSEN, T. SWENSEN, S. AUNE, AND J. MYREN

Transnasal bile duct catheterisation after endoscopic sphincterotomy P. B. COTTON, P. G. J. BURNEY, AND R. R. MASON

Distribution of HLA histocompatibility antigens, $\mathrm{ABO}$ blood groups and $\mathrm{Rh}$ antigens in alcoholic liver disease M. MELÉNDEZ, L. VARGAS-TANK, C. FUENTES, R. ARMAS-MERINO, D. CASTILLO, C. WOLFF, M. E. W'EGMANN, AND J. SOTO

Comparison of oral feeding of peptide and amino acid meals to normal human subjects D. B. A. SILK, Y. C. CHUNG, K. L. BERGER, K. CONLEY, M. BEIGLER, M. H. SLEISENGER, G. A. SPILLER, AND Y. S. KIM
Influence of intestinal transit time on azo-reduction of salicylazosulphapyridine (Salazopyrin) P. A. M. van HEES, J. H. M. TUINTE, J. M. van ROSSUM, AND J. H. M. Van TONGEREN

Nippostrongylus brasiliensis infection in the rat: effect of iron and protein deficiency on the anthelmintic efficacy of mebendazole, pyrantel, piperazine, and levamisole v. M. DUNCOMBE, T. D. BOLIN, A. E. DAVIS, M. R. FAGAN, AND J. D. KELLY

Proximal stomach and antrum in stomach emptying M. C. J. BARKER, I. COBDEN, AND A. T. R. AXON

\section{Clinical trial}

Rowachol-a possible treatment for cholesterol gallstones J. DORAN, M. R. B. KEIGHLEY, AND G. D. BELL

\section{Case reports}

Chronic non-specific ulcerative duodenojejunoileitis: report of four cases R. MODIGLIANI, P. POITRAS, A. GALIAN, B. MESSING, P. GUYET-ROUSSET, M. LIBESKIND, J. L. PIEL-DESRUISSEAUX, AND J. C. RAMBAUD

\section{Progress report}

Peptic ulcer in India and Bangladesh F. I. TOVEY

Notes and activities; Books

Copies are still available and may be obtained from the PUBLISHING MANAGER, BRITISH MEDICAL ASSOCIATION, TAVISTOCK SQUARE, LONDON WC1H 9JR, price $£ 3 \cdot 50$, including postage 